\title{
Screening for Antixenosis Resistance of Winter Wheat Genotypes to Cereal Leaf Beetles (Oulema melanopus L.)
}

\author{
Umer Bin Farook ${ }^{1 *}$, Zakir H. Khan', Ishtiyaq Ahad², Sheikh Aafreen', \\ Ishfaq Rafieq ${ }^{1}$, Tahir Yousuf ${ }^{3}$, Waseem Yousuf ${ }^{4}$, Suraya Jan ${ }^{5}$, \\ Adil Manzoor ${ }^{5}$ and Rubaida $\mathrm{Wani}^{5}$ \\ ${ }^{1}$ Division of Entomology, ${ }^{3}$ Div of Plant breeding and genetics, ${ }^{4}$ Div of Plant breeding and \\ genetics, Sher-e-Kashmir University of Agricultural Sciences and Technology of Kashmir, \\ Wadura Sopore, 193201, Kashmir, India \\ ${ }^{2}$ KVK Srinagar, India \\ ${ }^{5}$ CSIR IIIM Srinagar \\ *Corresponding author
}

A B S T R A C T

\section{Keywords \\ Antixenosis, Degree of damage, Incidence, \\ Triticum aestivum L., Oulema melanopus \\ Article Info \\ Accepted: 26 October 2018 Available Online: 10 November 2018}

The crop damage caused by cereal leaf beetles of the genus Oulema melanopus L (Coleoptera: Chrysomelidae) has been increased in recent decades. The purpose of these studies was to evaluate the antixenosis resistance to cereal leaf beetle in Indian wheat varieties/genotypes/advanced breeding lines of winter wheat (Triticum aestivum L.) created in India. The investigations were conducted under field conditions on natural infestation of existing population of cereal leaf beetle on wheat plants. The extent of differences between 33 genotypes was established to the infestation of cereal leaf beetles and their host suitability. The lowest incidence and degree of damage by cereal leaf beetles was observed in cultivar Ajanta i.e. 3.33 and $7 \%$ respectively while the highest incidence and degree of damage was found in cultivar HB-208 i.e. 35.55 and $37 \%$ respectively. Results of our investigations can contribute to the identification of genotypes as host plants of the cereal leaf beetles and their usage in the bridging process.

\section{Introduction}

Wheat is a key cereal crop for global food security as it constitutes an important source of calories and the main source of protein in more than 80 countries. In terms of calories, about $30 \%$ of the world population is dependent on wheat and its derivatives as primary sources of dietary energy, wheat being responsible for $13 \%$ to $57 \%$ of calorie intake depending on the country. Furthermore, wheat is the second principal source of calories in highly populated countries such as China and India as well as in 26 other countries, while in a further 16 countries it is the third principal calorie source. In total about $85 \%$ of the global population depends on wheat as a basic calorie source. India is today the second largest wheat producer in the whole world. Wheat cultivation has traditionally been dominated by the northern region of India and major wheat producing states are Uttar Pradesh, Punjab, Haryana, Madhya Pradesh, Rajasthan, Bihar, Maharashtra, Gujarat, Karnataka, West Bengal, Uttarakhand, Himachal Pradesh, and Jammu \& Kashmir. Out of these states Punjab and Haryana have been prolific wheat 
producers. In India, wheat is ravaged by a number of insect pests viz., Termites, Odontotermes obesus (Ramb); shoot fly, Atherigona naqvii (Steyskal); Brown wheat mite, Petrobia latens (Muller); Armyworm, Mythimna separata Walker); Cutworms, Agrotis ipsilon (Hufnagel) and Aphid, Sitobion avenae (Fabricius) (Deol, 1982). It has been estimated that global yield losses due to insect pests in the pre-green revolution era were about 5.1\%, however, the losses increased to $9.3 \%$ in the post-green revolution in 1990s (Dhaliwal et al., 2010). Insect pests are dynamic and highly adaptable. Changes in environmental temperature can modify their physiology, behavior, voltinism and distribution.

In recent decades economic damage caused by cereal leaf beetle is increasing. The cereal leaf beetles Oulema melanopus $\mathrm{L}$ is an oligophagous insects, whose host plants belong to the family Gramineae, but preferring wheat, barley and oats. In these agroecosystems, they are pests with economic importance. The phase of population gradation of O. melanopus and important economic damage were reported in North America (Olfert et al., 2004, 2006, Philips et al., 2011, Onychko 2012). The crop damage from cereal leaf beetles in certain areas of Europe could also lead to yield losses (Huusela-Veistola 2010, Tanasković et al., 2012, Onychko 2012). In a mass attack caused by Oulema spp., the assimilation processes of infested plant can be reduced up to $80 \%$ (Campbell et al., 1989) and yield losses reach 1t/ha, or 0.5$4 \%$ in winter wheat and $3-8 \%$ in barley (Ulrich et al., 2004).

The current control methods of this pests are mainly chemicals. The natural enemies (predators and parasitoids) have not a determining role in lowering the density or maintain them below the economic threshold (Laznik, 2010).
The modern tendency in the wheat breeding is not only aiming to increase the productivity of cultivars and to improve grain quality, but also to create plant cultivars, which are resistant to pests.

As the result, the effectiveness of plant breeding increases significantly, because the additional costs for the application of chemicals (insecticides) are not required and thus reduces the danger of environmental contamination. In this aspect, the growing of resistant varieties is a desirable non-chemical control method.

The purpose of these studies was to evaluate the antixenosis resistance to cereal leaf beetles in Indian wheat varieties/genotypes/advanced breeding lines of winter wheat (Triticum aestivum L.) created in India. The establishment of the resistance of wheat varieties and lines to biotic stress factors and the causes of specific reaction of genotypes, suggest studies on the suitability of various wheat genotypes as host plants of the cereal leaf beetles.

\section{Materials and Methods}

\section{Field trials and experimental genotypes}

This study was carried out at FOA SKUASTK Wadura campus during Rabi season (201718). A set of 30 wheat genotypes (released wheat varieties/advanced breeding lines/germplasm lines) with 3 check varieties were screened for their resistance against cereal leaf beetle. The cultivars were sown in Augmented Block Design with genotype to genotype spacing of $50 \mathrm{~cm}$ and plant to plant spacing of $10 \mathrm{~cm}$. The packages of practices were followed as per recommendations of SKUAST-K. However, no insecticidal treatment was given to experimental material. The genotypes were screened under natural infestation in the field. 


\section{Estimation methods}

The relative resistance of wheat genotypes against cereal leaf beetle Oulema melanopus was recorded on 3 plants per entry of each genotype.

The degree of damage was determined during the phase of flowering (BBCH 61-69) after the development of the larvae and was defined as a percentage of leaf area damaged by cereal leaf beetles over the entire surface of the leaf flag.

The percentage of flag leaf damaged was evaluated on a scale ranging from 1 to 5 (Rouag et al., 2012) on the basis of which varieties were classified as resistant, moderately resistant, moderately susceptible and Susceptible (Table 1).

\section{Statistical analysis}

Data obtained from the experiments have been analyzed using standard statistical procedures.

\section{Results and Discussion}

Incidence of cereal leaf beetle Oulema melonopus on different wheat genotypes

A perusal of data in figure 1 revealed that the Wheat cultivar 'HB-208 had the highest incidence of 35.55 per cent followed by GW120 with 31.11 per cent and was significantly different from it. The least incidence of 3.33 per cent was observed in cultivar AJANTA and hence the incidence ranged from 35.55 to 3.33 per cent and the total average for all genotypes was $18.89 \%$.

\section{Degree of damage by cereal leaf beetle on 33 wheat genotypes}

The degree of damage on the leaves of 33 wheat genotypes showed variation from 5 to $37 \%$ and the total average for all genotypes was $23.53 \%$.

Very low damages were reported on the Indian wheat varieties namely Ajanta (7\%) followed by GW-496 (9\%). The highest damage (37\%) was found on the cultivar HB208 , it was closely followed by GW-120, GW322, DL-788-2 and GW-173 with leaf damage of $36.9,35,35$, and 34.6 percent respectively.

The results obtained from percentage of leaf damage are presented in Figure 2, revealed that there 2 genotypes viz.,

Ajanta and GW-496 genotype were resistant; cultivars AKW-381, AKW-1071, C-306, CHHOTI LERMA, OPAN-1796, OPAN 3004, DBW-16, DL-784-3, DL-803, and gw190 were categorized as Moderately resistant; SW-1, SW-2, VL-22, HD-1925, HD-208, GW-503, GW-322, GW-273, GW-173, GW120, GW-89, GW-40, GW-10, DWR-195, DWR-39, DWR-16, DURGAPURA-65, DL788-2, DL-153-2, DBW-14 and D-134 as Moderately susceptible while as no genotype with complete susceptibility was found.

Table.1 Scale for scoring intensity of flag leaf damaged by cereal leaf beetle

\begin{tabular}{|c|c|c|}
\hline Scale & Percentage of flag leaf damaged & Grade \\
\hline $1-2$ & $<10 \%$ & Resistant varieties \\
\hline $2-3$ & $10-20 \%$ & Moderately Resistant varieties \\
\hline $3-4$ & $20-40 \%$ & Moderately Susceptible varieties \\
\hline $4-5$ & $>40 \%$ & Susceptible varieties. \\
\hline
\end{tabular}




\section{Different classes of infested flag leaves according to degree of attack}

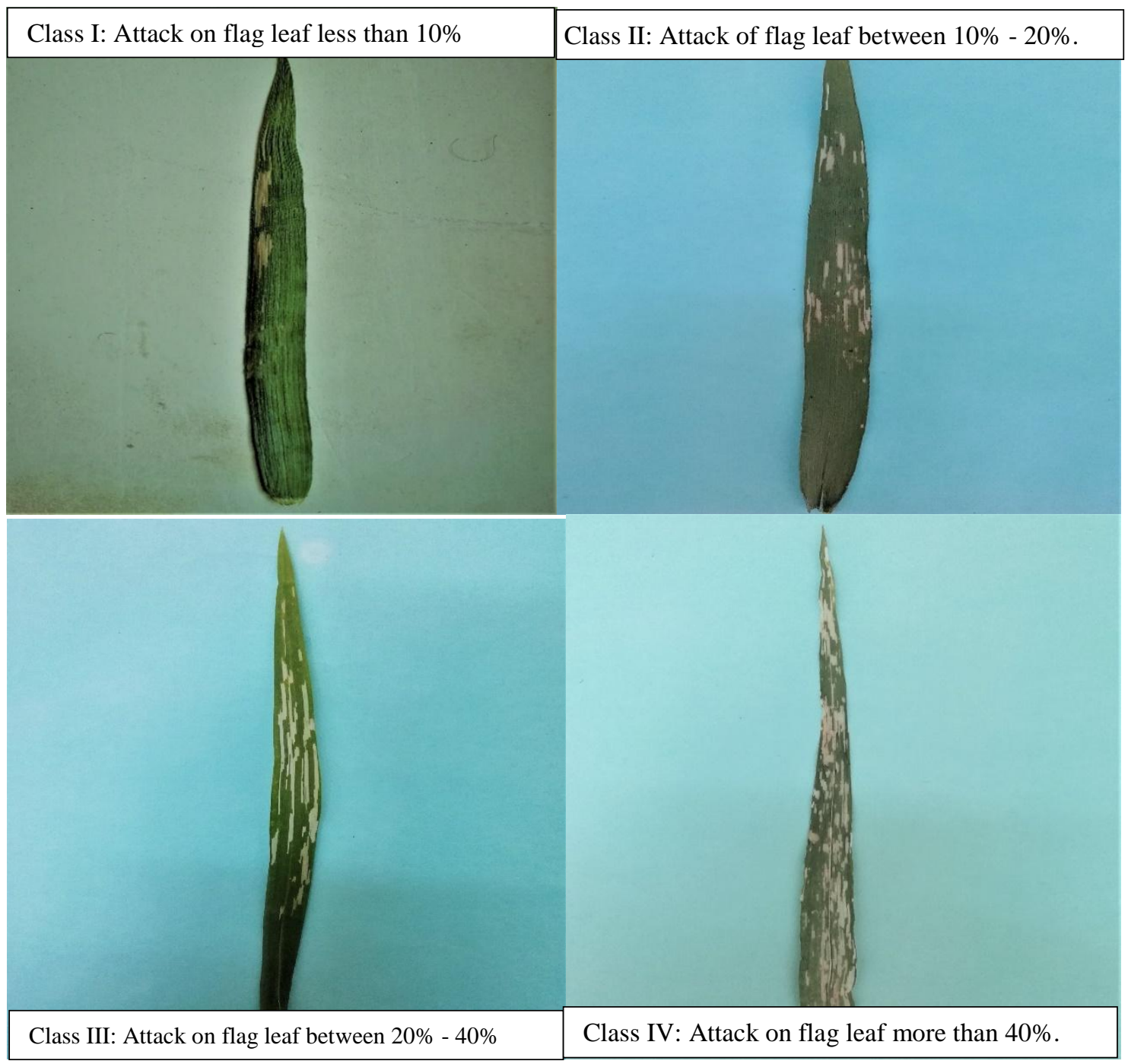

Fig.1 Incidence of Oulema melonopus on different wheat genotypes

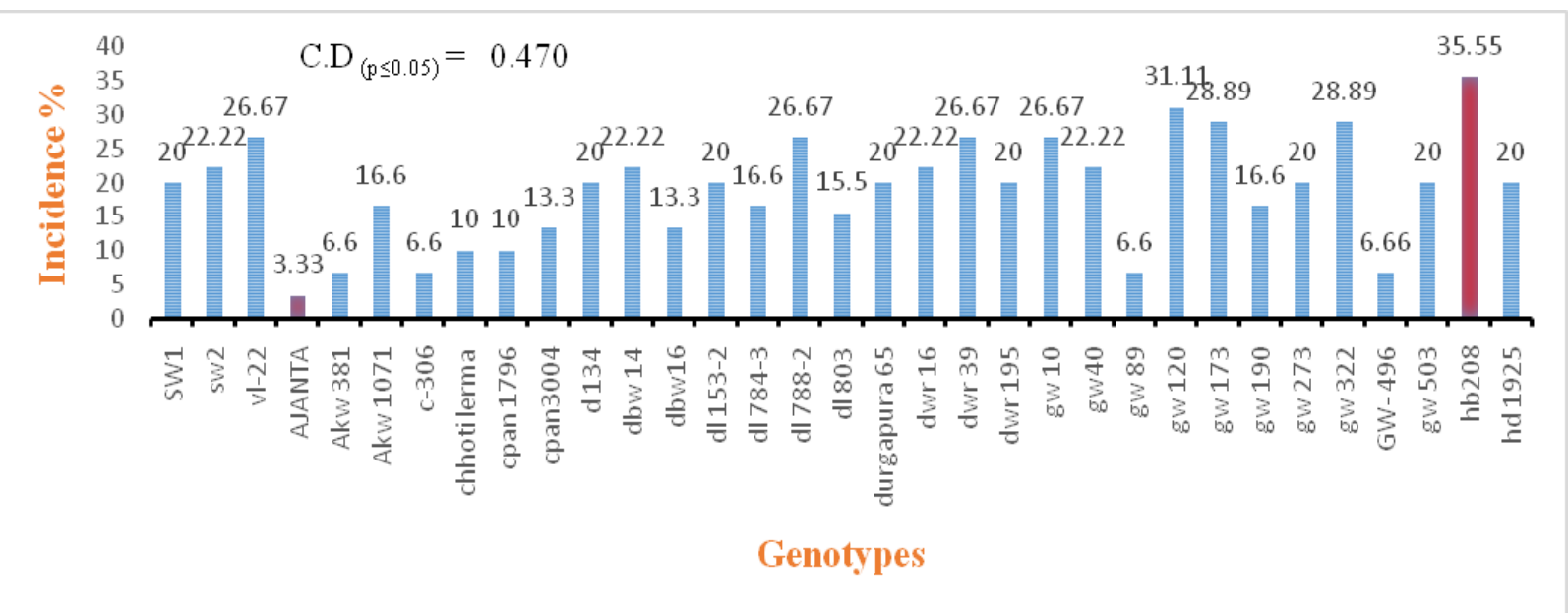


Fig.2 Degree of damage by Oulema melonopus on 33 wheat genotypes

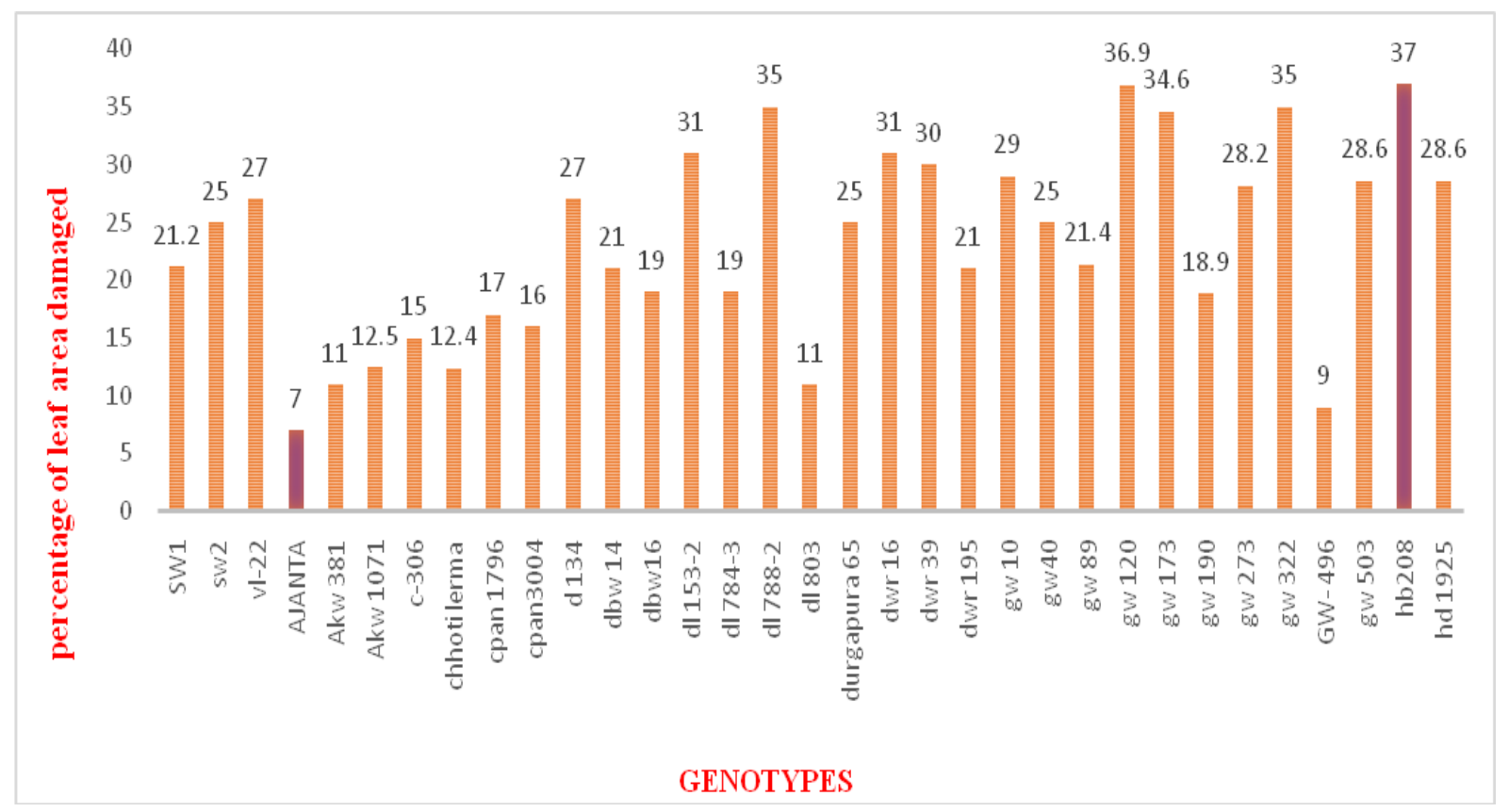

Table.2 Categorisation into resistant/susceptible genotype for relative resistance against $O$. melonopus

\begin{tabular}{|c|c|c|c|c|}
\hline S. no & Scale & $\begin{array}{c}\text { Percentage of } \\
\text { flag leaf damaged }\end{array}$ & Grade & Genotypes \\
\hline 1 & $1-2$ & $<10 \%$ & Resistant varieties & AJANTA, GW-496 \\
\hline 2 & $2-3$ & $10-20 \%$ & $\begin{array}{l}\text { Moderately Resistant } \\
\text { varieties }\end{array}$ & $\begin{array}{l}\text { AKW-381, AKW-1071, C-306, } \\
\text { CHOTTI LERMA, OPAN-1796, } \\
\text { OPAN-3004, DBW-16, DL-784-3, } \\
\text { DL-803, GW-190. }\end{array}$ \\
\hline 3 & $3-4$ & $20-40 \%$ & $\begin{array}{l}\text { Moderately } \\
\text { Susceptible varieties }\end{array}$ & $\begin{array}{l}\text { HD-1925, HD-208, GW-503, GW- } \\
\text { 322, GW-273, GW-173, GW-120, } \\
\text { GW-89, GW-40, GW-10, DWR-195, } \\
\text { DWR-39, DWR-16, DURGAPURA- } \\
\text { 65, DL-788-2, DL-153-2, DBW-14, } \\
\text { D-134, VL-22, SW-1, SW-2. }\end{array}$ \\
\hline 4 & $4-5$ & $>40 \%$ & Susceptible varieties & --- \\
\hline
\end{tabular}

Results indicate that some of the Indian wheat genotypes selected for their relative resistance to Oulema melanopus have mechanisms of non-preference (antixenosis) in terms of oviposition and feeding by the beetle. Lower feeding on plants of certain genotypes such as
AJANTA and GW-496 are indicative of antixenosis. Oulema melanopus did not feed actively on plants of the genotype AJANTA and GW-496. Adults feed actively when they are reproductively active and cause substantial damage to host plants (Haynes and 
Gage 1981; Kher et al., 2011); therefore, it was unusual that there was only slight feeding on AJANTA and GW-496 plants. This needs further exploration to identify plant morphological and biological characters that may be involved in hindering feeding and oviposition by adults. Other genotypes that appeared to exhibit greater antixenosis included AKW-381, AKW-1071, C-306, CHOTTI LERMA, OPAN-1796, OPAN3004, DBW-16, DL-784-3, DL-803, GW-190. Given that strong antixenosis is absent in HD1925, HD-208, GW-503, GW-322, GW-273, GW-173, GW-120, GW-89, GW-40, GW-10, DWR-195, DWR-39, DWR-16, DURGAPURA-65， DL-788-2， DL-153-2, DBW-14, D-134, VL-22, SW-1 and SW-2, it is important to test whether any of these genotypes possess antibiotic characters that may hinder $O$ melonopus physiology resulting in cessation of continued feeding or death.

Hence, antixenosis in most wheat genotypes results from a variety of plant morphological and physiological characters. Results of this examination can contribute to the identification of genotypes as suitable hosts of cereal leaf beetles and their usage in the bridging programs. We have not explored what mechanisms confer antixenosis in the genotypes we studied and this warrants further research.

\section{References}

Breiman, A., and Graur, D. 1995. Wheat evolution. Israel Journal of Plant Sciences, 43(2), 85-98.

Campbell, J.M., Sarazin, M.J., Lyons, D.B. 1989. Canadian beetles (Coleoptera) injurious to crops, ornamentals, stored products, and buildings. Agriculture Canada, Research Branch, Publication Agriculture Canada, 1989 - Nature- pp 491.
Deol, G. S., Gill, K. S., and Brar, J. S. 1987. Aphid outbreak on wheat and barley in Punjab. Newsl. Aphidol. Soc. India, 6: 7-9.

Dhaliwal, G.S., Jindal, V. and Dhawan, A. K. 2010. Insect pest problems and crop losses: changing trends. Indian Journal of. Ecological sciences 37, 1-7.

Haynes, D. L., and S. H. Gage. 1981. The cereal leaf beetle in North America. Annual Review of Entomology, 26: 259287.

Huusela-Veistola, E. 2010. Climate change and new pest problems in Finland. In NJF Seminar 430: Climate change and Agricultural Production in the Baltic Sea Region Vulnerability and Adaptation, Uppsala, Sweden, 4-6 May 2010, 6(1), 63

Kher, S. V., L. M. Dosdall, and H. A. Cárcamo. 2011. The cereal leaf beetle: biology, distribution and prospects for control. Prairie Soils and Crops, 4: 3241.

Laznik Z., Toth, T. Lakatos, T. Vidrih, M. Trdan, S. 2010. Oulema melanopus (L.) (Coleoptera: Chrysomelidae) adults are susceptible to entomopathogenic nematodes (Rhabditida) attack: results from a laboratory study. $J$. Pl. Disease Prot.117, 30-32.

Olfert, O., R. M. Weiss, S. Woods, H. Philip, L. Dosdall. 2004. Potential distribution and relative abundance of an invasive cereal crop pest, Oulema melanopus (Coleoptera: Chrysomelidae), in Canada. The Canadian Entomologist 136, 277-287.

Onychko B., Kovalenko, A. 2012. Monitoring the species composition of pests and diseases on crops spring crops in the North-eastern steppes of Ukraine [electronic resource] Bulletin of Sumy National Agrarian Univ: Research magazine.-Avg. "Agriculture and 
Biology" Sumy NAU. - Amounts, 9 (24), 19-22.

Philips, C. R., Herbert, D. A., Kuhar, T. P., Reisig, D. D., Thomason, W. E., Malone, S. 2011. Fifty years of cereal leaf beetle in the US: an update on its biology, management, and current research. Journal of Integrated Pest Management, 2(2), C1-C5.

Rouag N, Mekhlouf A, M. Makhlouf. 2012. Evaluation of infestation by cereal leaf beetles (Oulema spp.) on six varieties of durum wheat (Triticum dirum, Desf.) seedlings in arid 10 conditions of Setif, Algeria. Agric. Biol J N Am. 3, 525-528.

Tanasković, S., Madić M., Đurović D., Knežević D., F. Vukajlović. 2012.
Susceptibility of Cereal Leaf Beetle (Oulema melanopa L.) In Winter Wheat to Various Foliar Insecticides in Western Serbia Region. Romanian Agricultural Research 29, 361-366.

Tiwari, V. and Sharma, J. 2011. Soils, plant growth and crop production. Indian Journal of plant physiology, 1: 54-69

Ulrich W., Czarnecki, A., T. Kruszyński. 2004. Occurrence of pest species of the genus Oulema (Coleoptera: Chrysomelidae) in cereal fields in Northern Poland. Electronic Journal of Polish Agricultural Universities 7(1). http://www.ejpau.media.pl/articles/volu me7/issue 1/agronomy/art-04.pdf.

\section{How to cite this article:}

Umer Bin Farook, Zakir H. Khan, Ishtiyaq Ahad, Sheikh Aafreen, Ishfaq Rafieq, Tahir Yousuf, Waseem Yousuf, Suraya Jan, Adil Manzoor and Rubaida Wani. 2018. Screening for Antixenosis Resistance of Winter Wheat Genotypes to Cereal Leaf Beetles (Oulema melanopus L.). Int.J.Curr.Microbiol.App.Sci. 7(11): 3069-3073. doi: https://doi.org/10.20546/ijcmas.2018.711.352 